\title{
Regularization Path
}

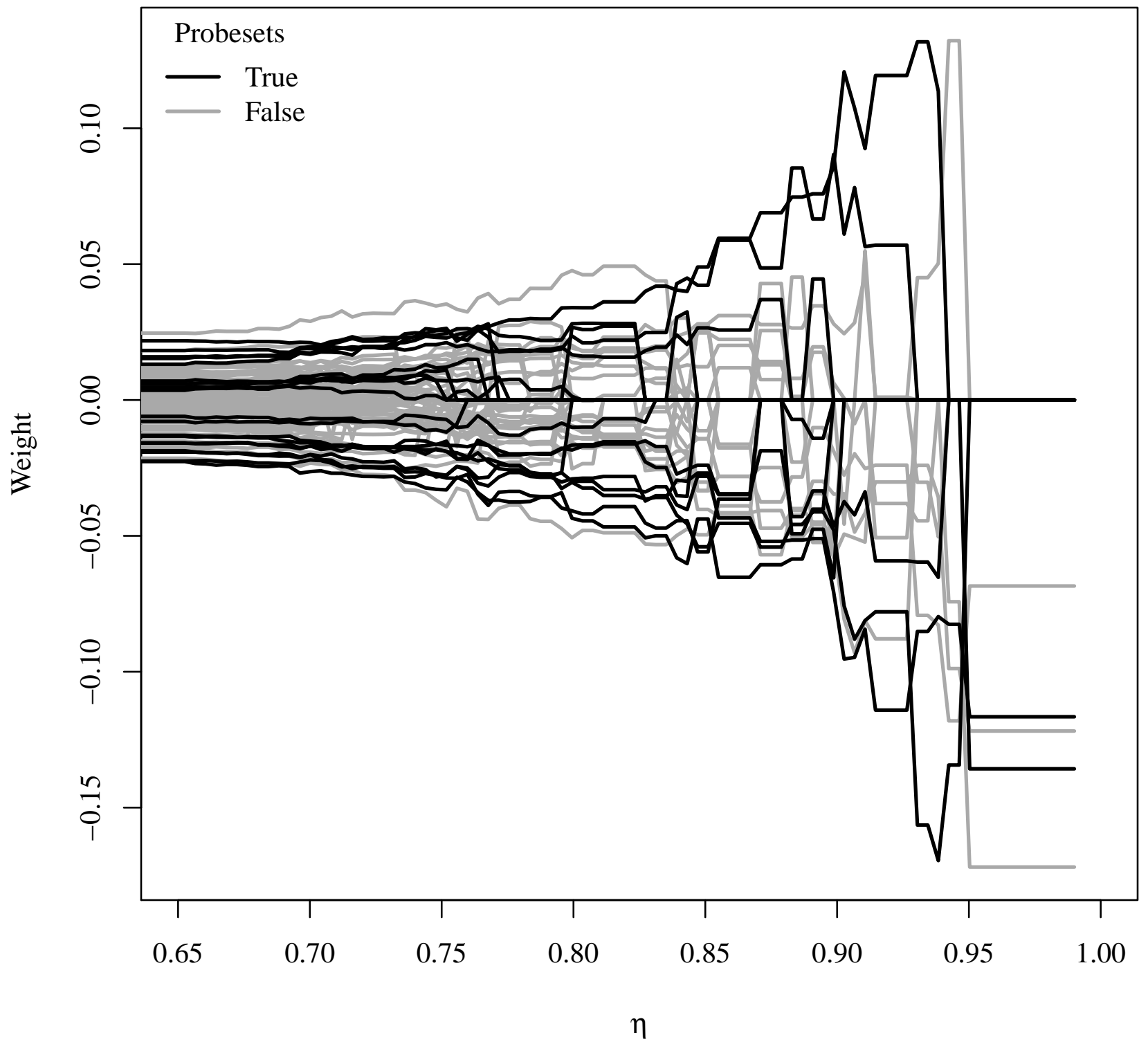

